Science, Technology and Development 34 (3): 135-139, 2015

ISSN 0254-6418 / DOI: 10.3923/std.2015.135.139

(C) 2015 Pakistan Council for Science and Technology

\title{
Dye-Sensitized Solar Cells Using Fifteen Natural Dyes as Sensitizers of Nanocrystalline $\mathrm{TiO}_{2}$
}

\author{
${ }^{1,2}$ Monzir S. Abdel-Latif, ${ }^{3}$ Mahmoud B. Abuiriban, ${ }^{4}$ Naji Al Dahoudi, \\ ${ }^{4}$ Amal M. Al-Kahlout, ${ }^{2,3}$ Sofyan A. Taya, ${ }^{2,3}$ Taher M. El-Agez and ${ }^{2,3}$ Hatem S. El-Ghamri \\ ${ }^{1}$ Department of Chemistry, \\ ${ }^{2}$ Renewable Energy Center, \\ ${ }^{3}$ Department of Physics, Islamic University of Gaza, Gaza, Palestinian Authority \\ ${ }^{4}$ Department of Physics, Al Azhar University, Gaza, Palestinian Authority
}

\begin{abstract}
In this study, dye-sensitized solar cells were fabricated using $\mathrm{TiO}_{2}$ as a semiconducting layer dyed with natural extracts. Thin layers of nanocrystalline $\mathrm{TiO}_{2}$ were deposited on transparent Fluorine doped tin oxide (FTO) conductive glass using doctor blade method. Fifteen natural dyes were examined as photosensitizers of the $\mathrm{TiO}_{2}$ layer. The absorption spectra of the natural extracts were performed. The $\mathrm{J}-\mathrm{V}$ characteristic curves of all fabricated cells were measured and analyzed. The parameters related to the cell performance were presented. Moreover, the impedance spectroscopy of two cells was investigated.
\end{abstract}

Key words: Dye-sensitized solar cells, natural dyes

\section{INTRODUCTION}

Energy is the greatest challenge facing mankind in this century. Energy sources are grouped into nonrenewable sources such as fossil fuel and renewable sources such as wind and solar energy. Nonrenewable sources such as fossil fuels have been the energy sources for human society for a long time. Fossil fuel is being rapidly depleted by excessive consumption and its burning has caused and is still causing damage to the earth environment. Renewable energy sources are considered clean alternatives to the traditional sources.

Dye-Sensitized Solar Cell (DSSC) was proposed by O'Regan and Gratzel (1991) and was classified as the third generation of photovoltaic devices for the conversion of visible light into electric energy. In DSSCs, light is absorbed in a single layer of dye molecules that is adsorbed on a layer of titanium dioxide $\left(\mathrm{TiO}_{2}\right)$ nano-particles spread on a conductive transparent glass. After light absorption, the excited dye molecule injects an electron into $\mathrm{TiO}_{2}$ film. The electron is transported to the conductive glass, where it is collected and transferred through a load. The positive charge is transferred from the dye to an electrolyte. Opposite of the $\mathrm{TiO}_{2}$ film is the counter electrode, where the electrolyte is reduced into its original state by the electron collected at $\mathrm{TiO}_{2}$ side of the cell.
The DSSCs have been a popular subject of research. Several natural dyes were used as sensitizers for DSSCs, such as cyanin (Hao et al., 2006; Calogero and Marco, 2008), carotene (Gomez-Ortiz et al., 2010), tannin (Espinosa et al., 2005) and chlorophyll (Kumara et al., 2006). Calogero and Marco (2008) obtained an efficiency of $0.66 \%$ using red sicilian orange juice dye as sensitizer for DSSCs. Wongcharee et al. (2007) used rosella as a sensitizer and achieved a conversion efficiency of $0.70 \%$. Rose Bengal dye was used as a sensitizer and achieved a short circuit current of $3.22 \mathrm{~mA} \mathrm{~cm}{ }^{-2}$, open circuit voltage of $0.89 \mathrm{~V}$ and conversion efficiency of $2.09 \%$ (Roy et al., 2008). Wang et al. (2007) used the coumarin dye as a DSSC sensitizer and the efficiency was 7.6\%. Zhou et al. (2011) investigated twenty natural dyes and got a highest efficiency of $1.17 \%$. Different natural dyes such as plant seeds and fresh and dried raw materials were investigated as photosensitizers for DSSCs and an efficiency of 0.725\% was obtained (El-Agez et al., 2012, 2014; Batniji et al., 2014).

In this study, DSSCs were fabricated using $\mathrm{TiO}_{2}$ as a semiconducting layer dyed with natural extracts. Many natural dyes were examined such as bougainvillea, passion fruit, clove grain, carob fruit, black tea leaves, green tea leaves, basil flower, mint flower, henna leaves, onions peel, royal poinciana, eggplant peel, eggplant pulp

Corresponding Author: Sofyan A. Taya, Renewable Energy Center, Islamic University of Gaza, Gaza, Palestinian Authority Tel: 009728 2644400/1025 Fax: 0097282644800 
and others. The absorption spectra of these dyes were carried out. The J-V characteristic curves of all fabricated cells were measured, plotted and analyzed. The impedance spectroscopy of two cells was conducted.

\section{MATERIALS AND METHODS}

Fifteen natural dyes were collected as follows: 4 dyes were extracted from plant flowers (bougainvillea, mint, basil and royal poinciana), 5 dyes were extracted from plant leaves (black tea, green tea, henna, schinus terebinthifolius and fig), 3 dyes were extracted from plant peel (passion, onion and eggplant) and 3 dyes were extracted from other natural sources (carob fruit, clove grain and eggplant pulp). The raw materials were washed with distilled water and left to dry at room temperature for a week. After drying and crushing into fine powder, $200 \mathrm{mg}$ of each powder was immersed in $5 \mathrm{~mL}$ ethanol at room temperature in the darkness for $24 \mathrm{~h}$ to extract the dyes. The extracts were filtered out to remove the remaining solids of the powder.

The absorption spectra of all extracts were carried out using a UV-VIS spectrophotometer (Thermoline Genesys 6) in the spectral range from $350-750 \mathrm{~nm}$.

Fluorine doped tin oxide (FTO) conductive glass sheet of dimension $1 \times 1 \mathrm{~cm}^{2}$ with sheet resistance of $15 \Omega \mathrm{cm}^{-2}$ and transmission $\geq 80 \%$ (Xingyan Tech. Ltd, Hong Kong) were first cleaned in a detergent solution using an ultrasonic bath for $10 \mathrm{~min}$, rinsed with water and ethanol and then dried. $\mathrm{TiO}_{2}$ paste was prepared by adding $50 \mathrm{mg}$ of $\mathrm{TiO}_{2}$ nanopowder to $100 \mathrm{mg}$ of polyethylene glycol then grinding the mixture for half an hour until a homogeneous paste was obtained. The paste was deposited on the FTO conductive glass sheets by doctor-blade method in order to obtain a $\mathrm{TiO}_{2}$ layer. The $\mathrm{TiO}_{2}$ layer was sintered at $450^{\circ} \mathrm{C}$ for $40 \mathrm{~min}$ (Taya et al., 2014; El-Ghamri et al., 2014). After cooling down to $60^{\circ} \mathrm{C}$, the thickness was measured using Olypus Polarizing Microscope BX53-P equipped with DP73 camera and found to be $22 \pm 1 \mu \mathrm{m}$. The samples were then immersed in the natural extracts for $24 \mathrm{~h}$ at $60^{\circ} \mathrm{C}$.

The cells were assembled by fixing the working electrode and the counter electrode by paper clips with a spacer between the electrodes. The redox electrolyte solution was composed of $2 \mathrm{~mL}$ acetonitrile (ACN), $8 \mathrm{~mL}$ propylene carbonate (p-carbonate), $0.668 \mathrm{mg}$ potassium iodide (KI) and $0.0634 \mathrm{mg}$ iodine $\left(\mathrm{I}_{2}\right)$. The redox electrolyte solution was sandwiched between the two electrodes.

The fabricated cells were illuminated (AM1.5) and the $\mathrm{J}-\mathrm{V}$ characteristic curves were conducted using National Instruments data acquisition card (USB NI 6251) in combination with a Labview program.
Impedance spectroscopy was conducted for two cells. When the impedance spectroscopy measurements are performed in the dark, the method is called Electrochemical Impedance Spectroscopy (EIS). If the cell is illuminated during impedance measurements, the method is called Photoelectrochemical Impedance Spectroscopy (PEIS). The EIS was conducted using a Potentiostat-galvanostat Autolab PGSTAT-30N with FRA32M module. Impedance measurements where performed at frequencies between 0 and $100 \mathrm{KHz}$ with an AC signal of $0.6 \mathrm{~V}$ amplitude. The equivalent circuit was derived from the rate of electron transfer and lifetime of the electron in the film which are consistent with the values derived from the transient photocurrent and photovoltage measurements.

\section{RESULTS AND DISCUSSION}

The absorption spectra of two dyes are shown in Fig. 1. The figure shows that there are absorption peaks at 432 and $666 \mathrm{~nm}$ for the extract of fig leaves whereas, the extract of schinus terebinthifolius leaves has absorption peaks at 414 and $666 \mathrm{~nm}$. The peaks at about $660 \mathrm{~nm}$ are characteristic absorption spectrum of chlorophyll a. The wide absorption bands in the region from 400-500 nm may be attributed to a combined absorption of the chlorophyll Soret bands as well as the presence of quantities of carotenoids co extracted with the pigment. All values of the maximum absorption wavelength of the natural pigments are listed in Table 1. As illustrated in the Table, most of the extracts were found to have an absorption peak at $\sim 660 \mathrm{~nm}$.

The J-V measurements of the fabricated DSSCs were conducted under an illumination of $100 \mathrm{~mW} \mathrm{~cm}^{-2}$. Figure 2 illustrates the $\mathrm{J}-\mathrm{V}$ characteristic curves obtained

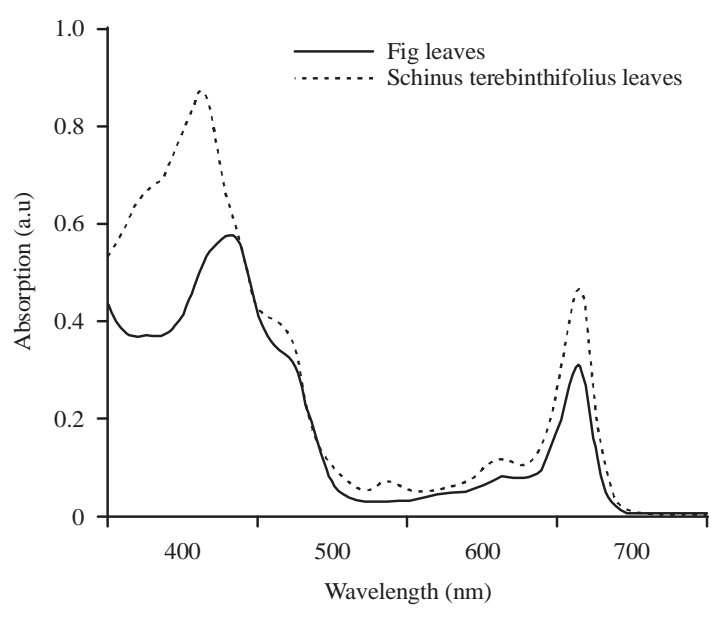

Fig. 1:Absorption spectra of fig and schinus terebinthifolius leaves using ethanol as a solvent 


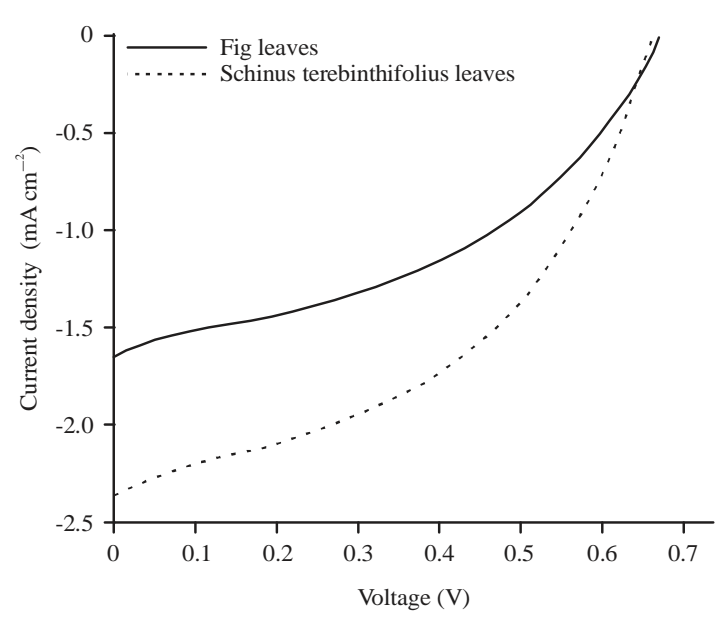

Fig. 2: J-V characteristic curves of the DSSCs sensitized with fig and schinus terebinthifolius leaves

Table 1: Parameters of the fabricated DSSCs

\begin{tabular}{lccccc}
\hline Extracts & $\begin{array}{l}\lambda \mathrm{max} \\
(\mathrm{nm})\end{array}$ & $\begin{array}{l}\mathrm{J}_{\mathrm{SC}} \\
\left(\mathrm{mA} \mathrm{cm}^{-2}\right)\end{array}$ & $\begin{array}{c}\mathrm{V}_{\mathrm{OC}} \\
(\mathrm{V})\end{array}$ & $\mathrm{FF}$ & $\eta(\%)$ \\
\hline Bougainvillea & 666 & 0.80 & 0.57 & 0.38 & 0.18 \\
Mint flower & 664 & 0.45 & 0.56 & 0.38 & 0.09 \\
Basil flower & 664 & 1.12 & 0.60 & 0.40 & 0.27 \\
Royal poinciana & 448 & 0.84 & 0.63 & 0.42 & 0.22 \\
Black tea leaves & 666 & 0.39 & 0.55 & 0.40 & 0.08 \\
Green tea leaves & 410 & 0.22 & 0.47 & 0.26 & 0.03 \\
& 666 & & & & \\
Carob fruit & 662 & 0.41 & 0.58 & 0.43 & 0.10 \\
Clove grain & 666 & 0.60 & 0.55 & 0.42 & 0.14 \\
Henna leaves & 410 & 0.30 & 0.49 & 0.35 & 0.05 \\
& 666 & & & & \\
Passion peel & 666 & 0.78 & 0.63 & 0.39 & 0.19 \\
Onion peel & & 0.45 & 0.55 & 0.47 & 0.12 \\
Eggplant peel & 416 & 0.23 & 0.53 & 0.29 & 0.04 \\
& 664 & & & & \\
Eggplant pulp & 668 & 0.35 & 0.63 & 0.39 & 0.09 \\
Fig leaves & 432 & 1.60 & 0.67 & 0.45 & 0.49 \\
Schinus & 666 & & & & \\
terebinthifolius leaves & 666 & & & & \\
\hline
\end{tabular}

for the DSSCs sensitized with fig and schinus terebinthifolius leaves. To evaluate a solar cell performance, the following parameters should be determined: short circuit current density $\left(\mathrm{J}_{\mathrm{SC}}\right)$, open circuit voltage $\left(V_{\text {OC }}\right)$, Fill Factor (FF) and efficiency $(\eta)$. The fill factor and conversion efficiency are calculated using these parameters. All the photoelectrochemical parameters of the fabricated cells are presented in Table 1 . As illustrated in the table, the short circuit current density varied from $0.22-2.40 \mathrm{~mA} \mathrm{~cm}{ }^{-2}$. The highest short circuit current density was obtained for the DSSC sensitized with schinus terebinthifolius leaves and the lowest one was obtained for the DSSC sensitized with green tea leaves. Relatively high short circuit current densities of 2.40, 1.60 and $1.12 \mathrm{~mA} \mathrm{~cm}^{-2}$ were obtained for DSSCs sensitized with schinus terebinthifolius leaves, fig leaves and basil flower, respectively. The open circuit voltage varied from $0.47 \mathrm{~V}$ for the DSSC sensitized with green tea leaves to $0.68 \mathrm{~V}$ for the DSSC sensitized with schinus terebinthifolius leaves. The power was calculated for each experimental point by multiplying the current and voltage of the point. The maximum power point of each cell was then determined. The highest power of $0.73 \mathrm{~mW} \mathrm{~cm}{ }^{-2}$ was obtained for the DSSC sensitized with schinus terebinthifolius leaves. The FF of the fabricated cells was found to vary from $0.26-0.47$. The DSSC sensitized with onion peel was found to have the highest FF whereas, the DSSC sensitized with green tea leaves had the lowest FF. The table also shows that the conversion efficiency ranged from 0.03 for the DSSC sensitized with green tea leaves to 0.73 for the DSSC sensitized with schinus terebinthifolius leaves. The highest efficiencies of 0.73 , $0.49,0.27$ and 0.22 were obtained for the DSSCs sensitized with schinus terebinthifolius leaves, fig leaves, basil flower and Royal Poinciana, respectively. These values for the cell photoelectrochemical parameters are comparable to those obtained in many previous works based on natural dyes. Hao et al. (2006), DSSCs were fabricated by using natural dyes extracted from black rice, capsicum, erythrina variegata flower, rosa xanthina and kelp. The $\mathrm{J}_{\mathrm{SC}}$ ranged from 0.225-1.142 $\mathrm{mA} \mathrm{cm}-^{2}$ and the $\mathrm{V}_{\mathrm{OC}}$ varied from $0.412-0.551 \mathrm{~V}$. Zhou et al. (2011), twenty natural dyes extracted from natural materials such as flowers and leaves were used as sensitizers for DSSCs. The photoelectrochemical performance of the DSSCs based on these dyes showed that the $\mathrm{V}_{\mathrm{OC}}$ varied from $0.337-0.689 \mathrm{~V}$, the $\mathrm{J}_{\mathrm{SC}}$ ranged from $0.14-2.69 \mathrm{~mA} \mathrm{~cm}^{-2}$ and the highest efficiency was $1.17 \%$.

The DSSCs sensitized with fig and schinus terebinthifolius leaves were found to have the best performance, so they were investigated using EIS using a Potentiostat-galvanostat Autolab PGSTAT-30N with FRA32M module. Impedance measurements were performed at frequencies between 0 and $100 \mathrm{KHz}$ with an AC signal of $0.6 \mathrm{~V}$ amplitude at room light and temperature. Figure 3 shows (a) Nyquist plots, (b) Bode plots and (c) and (d) Equivalent circuits of the two cells dyed with fig and schinus terebinthifolius leaves. The equivalent circuits show large series resistance and the low shunt resistance. These values of the series and shunt resistances can explain the low fill factor of the fabricated DSSCs which ranged from 0.26-0.47. Series resistance may be attributed to ohmic resistance and poor connection between material interfaces. Moreover, low mobility of the electrolyte can contribute to the series resistance. Low shunt resistance indicates that the current has alternative 
Sci. Technol. Dev., 34 (3): 135-139, 2015
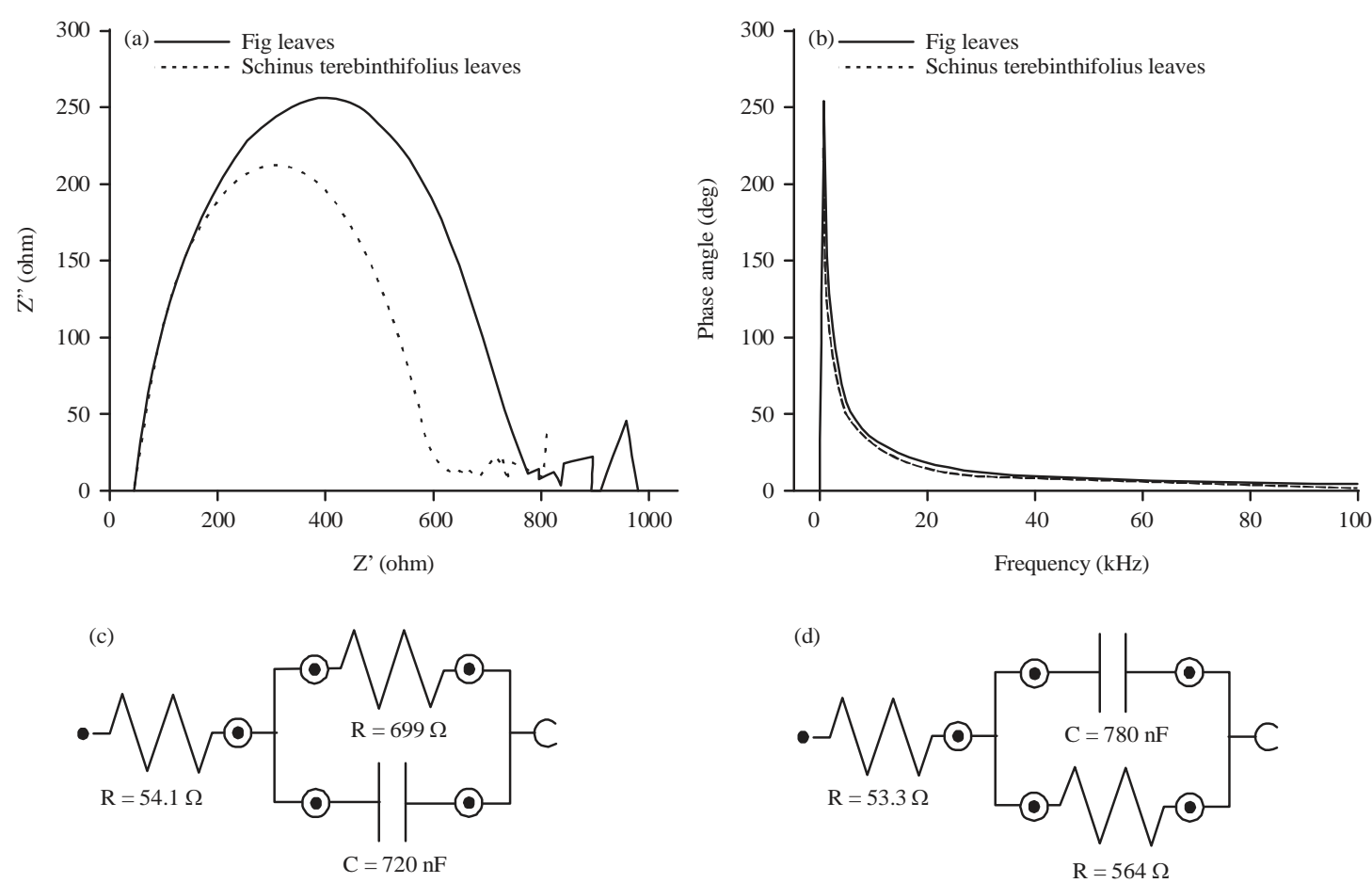

Fig. 3(a-d): Output of the EIS for DSSCs sensitized with fig and schinus terebinthifolius leaves (a) Nyquist plots, (b) Bode plots, (c) Fig leaves (equivalent circuit) and (d) Schinus terebinthifolius leaves (equivalent circuit)

ways of crossing the cell other than the desired one, e.g., if the $\mathrm{TiO}_{2}$ electrode is in almost direct contact with counter electrode. The performance of the fabricated cells can be significantly improved by enhancing the fill factor.

\section{CONCLUSION}

In this study, fifteen natural dyes were used as photosensitizers for DSSCs. These dyes include plant leaves, flowers and fruits. The absorption spectra of the natural extracts were carried out. The J-V characteristic curves of all fabricated cells were measured and analyzed. The parameters related to the cell performance were presented. Moreover, the impedance spectroscopy of two cells was investigated.

Plant leaves showed higher efficiencies than other parts of trees due to the presence of chlorophyll. The best performance was obtained for the DSSC sensitized with Schinus terebinthifolius leaves with photoelectrchemical parameters of $\mathrm{J}_{\mathrm{SC}}=2.40 \mathrm{~mA} \mathrm{~cm}{ }^{-2}, \mathrm{~V}_{\mathrm{OC}}=0.68, \mathrm{FF}=0.44$ and $\eta=0.73$.

\section{ACKNOWLEDGMENT}

The authors would like to express gratitude to the ministry of higher education for the financial support of this study.

\section{REFERENCES}

Batniji, A.Y., R. Morjan, M.S. Abdel-Latif, T.M. El-Agez, S.A. Taya and H.S. El-Ghamri, 2014. Aldimine derivatives as photosensitizers for dye-sensitized solar cells. Turk. J. Phys., 38: 86-90.

Calogero, G. and G. Di Marco, 2008. Red Sicilian orange and purple eggplant fruits as natural sensitizers for dye-sensitized solar cells. Solar Energy Mater. Solar Cells, 92: 1341-1346.

El-Agez, T.M., A.A. El Tayyan, A. Al-Kahlout, S.A. Taya and M.S. Abdel-Latif, 2012. Dye-sensitized solar cells based on $\mathrm{ZnO}$ films and natural dyes. Int. J. Mater. Chem., 2: 105-110.

El-Agez, T.M., S.A. Taya, K.S. El-Refi and M.S. Abdel-Latif, 2014. Dye-sensitized solar cells using some organic dyes as photosensitizers. Optica Applicata, 44: 345-351.

El-Ghamri, H.S., T.M. El-Agez, S.A. Taya, M.S. Abdel-Latif and A.Y. Batniji, 2014. Dye-sensitized solar cells with natural dyes extracted from plant seeds. Mater. Sci. Poland, 32: 547-554.

Espinosa, R., I. Zumeta, J.L. Santana, F. Martınez-Luzardo, B. Gonzalez, S. Docteur and E. Vigil, 2005. Nanocrystalline $\mathrm{TiO}_{2}$ photosensitized with natural polymers with enhanced efficiency from 400 to 600 nm. Solar Energy Mater. Solar Cells, 85: 359-369. 
Gomez-Ortiz, N.M., I.A. Vazquez-Maldonado, A.R. PerezEspadas, G.J. Mena-Rejon, J.A. AzamarBarrios and G. Oskam, 2010. Dye-sensitized solar cells with natural dyes extracted from achiote seeds. Solar Energy Mater. Solar Cells, 94: 40-44.

Hao, S., J. Wu, Y. Huang and J. Lin, 2006. Natural dyes as photosensitizers for dye-sensitized solar cell. Solar Energy, 80: 209-214.

Kumara, G.R.A., S. Kaneko, M. Okuya, B. Onwona-Agyeman, A. Konno and K. Tennakone, 2006. Shiso leaf pigments for dye-sensitized solid-state solar cell. Solar Energy Mater. Solar Cells, 90: 1220-1226.

O'Regan, B. and M. Gratzel, 1991. A low-cost, high-efficiency solar cell based on dye-sensitized colloidal $\mathrm{TiO}_{2}$ films. Nature, 353: 737-740.

Roy, M.S., P. Balraju, M. Kumar and G.D. Sharma, 2008. Dye-sensitized solar cell based on Rose Bengal dye and nanocrystalline $\mathrm{TiO}_{2}$. Solar Energy Mater. Solar Cells, 92: 909-913.
Taya, S.A., T.M. El-Agez, M.S. Abdel-Latif, H.S. El-Ghamri, A.Y. Batniji and I.R. El-Sheikh, 2014. Fabrication of dye-sensitized solar cells using dried plant leaves. Int. J. Renewable Energy Res., 4: 384-388.

Wang, Z.S., Y. Cui, K. Hara, Y. Danoh, C. Kasada and A. Shinpo, 2007. A high-light-harvesting-efficiency coumarin dye for stable dye-sensitized solar cells. Adv. Mater., 19: 1138-1141.

Wongcharee, K., V. Meeyoo and S. Chavadej, 2007. Dye-sensitized solar cell using natural dyes extracted from rosella and blue pea flowers. Solar Energy Mater. Solar Cells, 91: 566-571.

Zhou, H., L. Wu, Y. Gao and T. Ma, 2011. Dye-sensitized solar cells using 20 natural dyes as sensitizers. J. Photochem. Photobiol. A: Chem., 219: 188-194. 